Environmental Research Journal 13 (1-4): 35-50, 2019

ISSN: $1994-5396$

(C) Medwell Journals, 2019

\title{
Integration of Environmental Justice to the Management of Forest Ecosystems in South-South Region of Nigeria
}

\author{
Owolabi Babatunde Oluwaseyi \\ Department of Urban and Regional Planning, Federal University of Technology Akure, \\ Ondo State, Akure, Nigeria
}

\begin{abstract}
Globally, wetland ecosystems provide a wide range of ecosystems services useful for both local and national communities. The upper Orashi wetland of international importance have witnessed severe depletion Edue to anthropogenic activities and poor management practices that are not able to promote justice within the environment South-South region of Nigeria. This study assessed the progress towards Environmental Justice (EJ) in the management of the Upper Orashi forest reserve. The case study research approach was adopted to identify upper Orashi forestreserve and the management system put in place. Spatially disaggregated ecosystem datasets and multi-temporal Landsat imageries were subjected to image analysis and processed using a supervised classification GIS technique to assess changes in ecosystem biomes in the forest between 1988 and 2018. The study made use of the benefit transfer technique for monetary valuation of ecosystems and the value depleted over the 30 year period. The study then assessed progress towards EJ using a suite of indicators for its dimensions, performance scoring and guidance notes. Results indicate that the ecosystems and their services have greatly depleted. Monetarily, $\$ 1.815$ billion (N635.5 billion) worth of the ecosystem services of the forest has been lost over the period. It was also found out that the management system for Upper Orashi forest did not achieve the standard achievement mark of EJ, indicating a high level of environmental injustice in the study area. This calls for continuous valuation and assessment of the Upper Orashi forest reserve and its ecosystem services using updated environmental indicators tools to progress environmental justice.
\end{abstract}

Key words: Ecosystem services, ecosystem valuation, environmental justice, forest reserve, wetlands, assessment

\section{INTRODUCTION}

Wetlands are a very important source of natural resources upon which many rural economies and entire societies depend (United State Environmental Protection Agency (USEPA), 2006). Wetlands are essential sources for food, fresh water and building materials and they provide valuable services such as water treatment, erosion control and flood protection (Kirsten and Brander, 2004; USEPA., 2006). Despite the importance of wetlands to human survival, much of the world's wetlands have been lost, thus bringing about alterations and loss in the services they provide (Day et al., 2000; Finlayson, 2005. Human perception of wetlands as unproductive, unhealthy lands, full of disease carrying insects and reptiles such as snakes and crocodiles is a major cause of the loss and degradation (Ajibola et al., 2016). The declining condition of wetlands has placed their ecosystem services and the people who depend on them at increasing risk. Indeed, ICSU as cited in (Wali, 2017) about 50\% of the world's wetlands have been depleted out of 1,280 million hectares. These loss and degradation are associated with reclamation of wetlands for other uses (Li et al., 2018).
The impact of the loss and degradation is mostly felt in coastal wetlands than in any other type of wetland. Coastal wetlands lie between land and ocean and are threatened by human activities and natural hazards such as climate change, sea level rise, local subsidence, decreased sediment supply and acidification ( $\mathrm{Li}$ et al., 2018). The rate of wetland loss has been so, drastic as the rich wetlands are being seriously threatened by a number of anthropogenic and biophysical factors (Uluocha and Okeke, 2004). Some of the notable human actions include population pressure, rapid urbanization, mining, oil and industrial waste pollution, overgrazing, logging, dam construction, transportation routes and other physical infrastructure (Uluocha and Okeke, 2004). The lack of effective participation of the local communities in the decision making as it is related to managing the wetlands around them and absence of adequate recognition of social norms and the believes of the local people results to social injustice within the management context (Young, 2000). The outcome of social injustice has led to conflicts and agitations between the managing bodies or parties and the local communities. 
Environmental justice can therefore be defined. In Africa, wetlands are generally recognised as land area where water saturation is the dominant factor determining the nature of the soil development, types of soil development and the types of plant and animal community living in the soil and on its surface and generally includes swamps, marshes, bogs and similar areas.

Statement of the problem: Wetlands are generally recognised as very productive and valuable ecosystems that provide good and services that are important for human well-being. Of all the different types of wetlands, coastal wetland ecosystem is estimated to contribute about $40 \%$ to global ecosystem services (Herbst, 2015) and is termed the most productive wetlands in the world. However, wetlands are experiencing unprecedented rates of loss (Day et al., 2000; Reid et al., 2004) which has led to several alterations in the services it provides causing environmental, economic and socio-political perturbations with significant impacts on biodiversity and community livelihood (Odada et al., 2009). Human activities are major factor that contributes to wetland loss and degradation and these activities include land conversion, infrastructural development, water withdrawal, pollution and over-harvesting. Specifically in the Niger-Delta region is the upper Orashi forests which is experiencing increasing rate of depletion due to uncontrolled activities of the local communities (Ogunkoya and Dami, 2007). This is also compounded by the government distancing themselves from managing the forest giving the local communities full access to exploit the forest resources unsustainably (Ogunkoya and Dami, 2007). The major human activities within and around the upper Orashi forest that serve as threat to the Upper Orashi Forests include farming, fishing, sand dredging, agroforestry, collection of wild resources, cottage industry and tourism (Ogunkoya and Dami, 2007; Svarstad et al., 2011). Deforestation of vast areas of land in the name of human progress has led to incalculable loss of both flora and fauna species. Local knowledge about the ecosystems values were attributed to the marketable ones at the expense of the non-marketable services which is one of the major factors inducing depletion of the forest. This study will therefore evaluate the trend of ecological and social injustice within and around the forest reserve in an attempt to integrate environmental justice into the management of Upper Orashi forest reserve in order to sustain the ability of the forest to provide all the services.

\section{Research questions:}

- What are the wetland ecosystems and wetland ecosystem services within Upper Orashi forest reserve?
- To what extent has the wetland ecosystems been depleted?

- What is the economic worth of the forest reserve in total?

- How has environmental justice been applied in the management Upper Orashi forest reserve?

\section{Aim and objectives}

Aim: The aim of this study is to integrate Environmental justice into the management of Upper Orashi forest reserve with a view to ensuring sustainability in the services the wetland ecosystem provides.

Objectives: In other to achieve the aim of this study, the following objectives would be to:

- Assess the Upper Orashi wetland ecosystems and their services

- Evaluate the extent of depletion of individual ecosystems in the study area

- Estimate the economic value of the wetland ecosystems in its pristine and depleted state

- Determine the level of justice in the existing management system

Justification of the study: Wetland ecosystems are important environmental and natural resource that form part of the total wealth of a nation. However because many of its benefits are not traded in the open market, their values are not captured using the conventional approaches to valuation, thereby ignored in the systems of national accounts (Ajibola et al., 2016). It is very important to understand that the physical ecosystem (ecological environment) sits within a broader socio-economic ecosystem (social or human environment) and any management strategy or approach that will be devised must be capable of catering for both ecosystems. Environmental justice is a tool that caters for both the ecological environment as well as the human environment. It deals with the concept of fairness and emphasizes fair distribution of benefits (Schlosberg, 2009). When talking about environmental justice, it's not about advocating for the human society or ecosystem but rather it involves fair treatment of both the ecological and the human environment. Individuals who benefit most from the conservation of wetlands are often the local communities and they are often excluded from decision making process. Solutions to ensure protection of these fragile environments while maintaining the livelihood benefits to local people need a multi-pronged approach that will effectively involve all stakeholders, especially, local communities in the decision-making process. This research is therefore expected to provide further and more detailed information on the various 


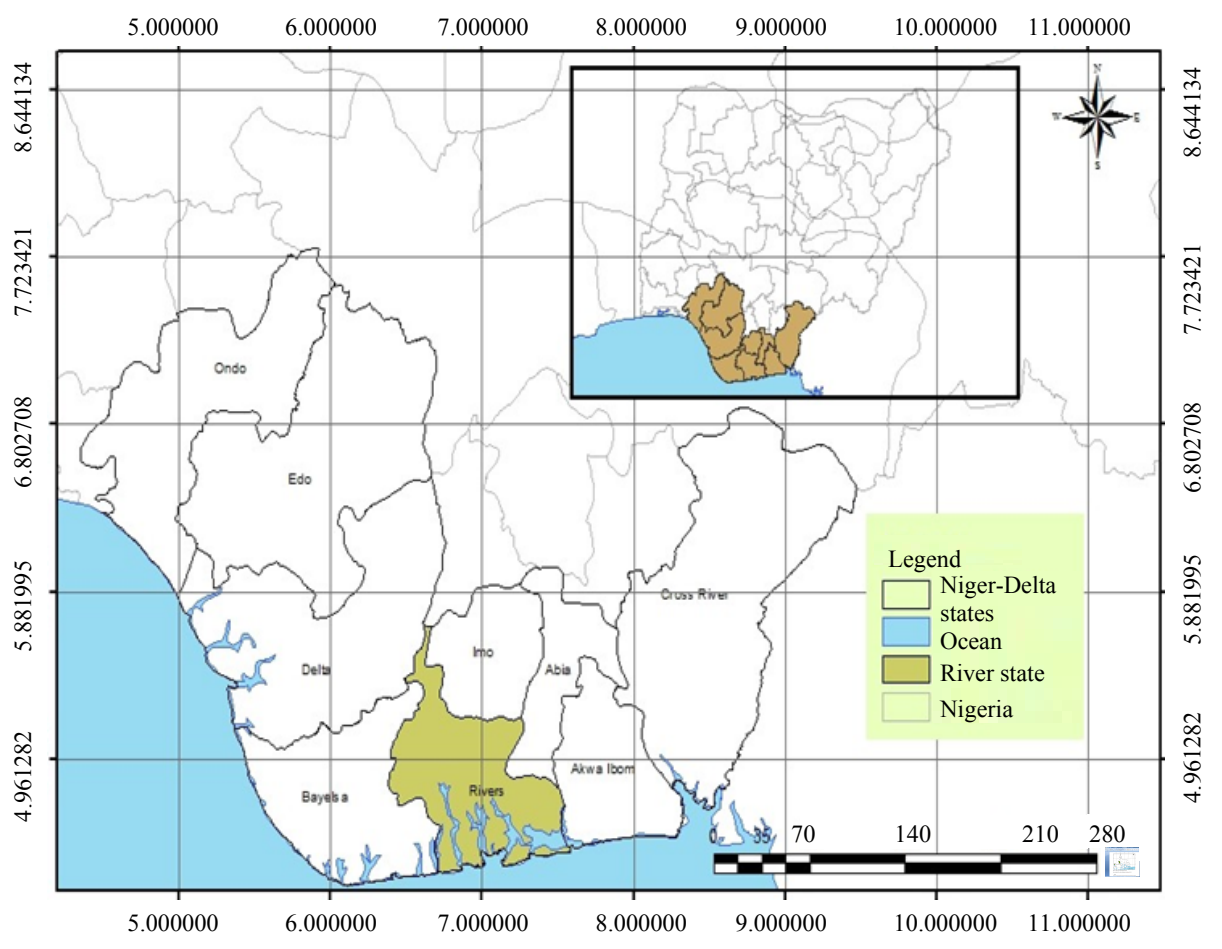

Fig. 1: Map of Nigeria showing rivers state within the Niger-Delta region Goggle Earth Pro, researchers digitization with ArcMap 10.5, 2019.

ecosystems within Upper Orashi forest reserve and the services they provide to both local and national societies, estimate the economic value of the ecosystems, evaluate the trend of depletion and access the effectiveness of the existing management strategies.

Scope of study: The study area which is Upper Orashi forests falls within this region at the South Western part of Rivers state in the South-South region of Nigeria Fig. 1. Various ecosystems within the study area would be studied to know the extent of their distribution and the services provided by the ecosystems, the causes and trend of the depletion of the ecosystems over time will also be evaluated after which the economic values of the ecosystems within the study area would be estimated and consequently, the level of justice in the existing management would be accessed and improved upon to control and reduce the rate of depletion of the forest reserve in order to ensure sustainability in its ability to provide the required services. The of the distribution of the wetland ecosystems and the extent of depletion would be assessed with the use of geo-spatial tools (ArcGis and Erdas imagine), interview guides would be employed to assess the various ecosystem services provided by Upper Orashi forests and the level of justice in the existing management using the key dimensions of environmental justice and finally the simple benefit transfer method would be employed in estimating the economic values of the forest ecosystem services.

\section{Study area}

Location and description: Upper Orashi forest reserve is an ecological community that is located in the central part of Niger Delta and in the Western part of rivers state, extending through three local government area in the state namely the Ahoada West, the Ahoada East and Abua local government areas. Geographically, it is located west of the nun branch, South of the section of Nigeria's 'East-West Road' linking Ahoada and in an area bounded by Bayelsa state boundary to the west and Orashi river to the North and East It covers a total land area of 25,165 ha with geographical coordinates $04^{\circ} 53^{\prime} \mathrm{N} 006^{\circ} 30^{\prime} \mathrm{E}$ and an elevation of $35 \mathrm{~m}$ above sea level. The forest reserve is pre dominantly a freshwater swamp forest (coastal wetland) ecosystem with few coverages of rainforests and mangrove ecosystems. Some of the rural settlements within the reserve include Odon, Emelego, Adoda, Illogovia, Ekunnga, Amenboko and Okolomaeh (Fig. 2).

Climate: The climate of Upper Orashi is the tropical monsoon climate and is characterized by lengthy wet season from March to November and a very short period of dry season from December to February. The forest has 


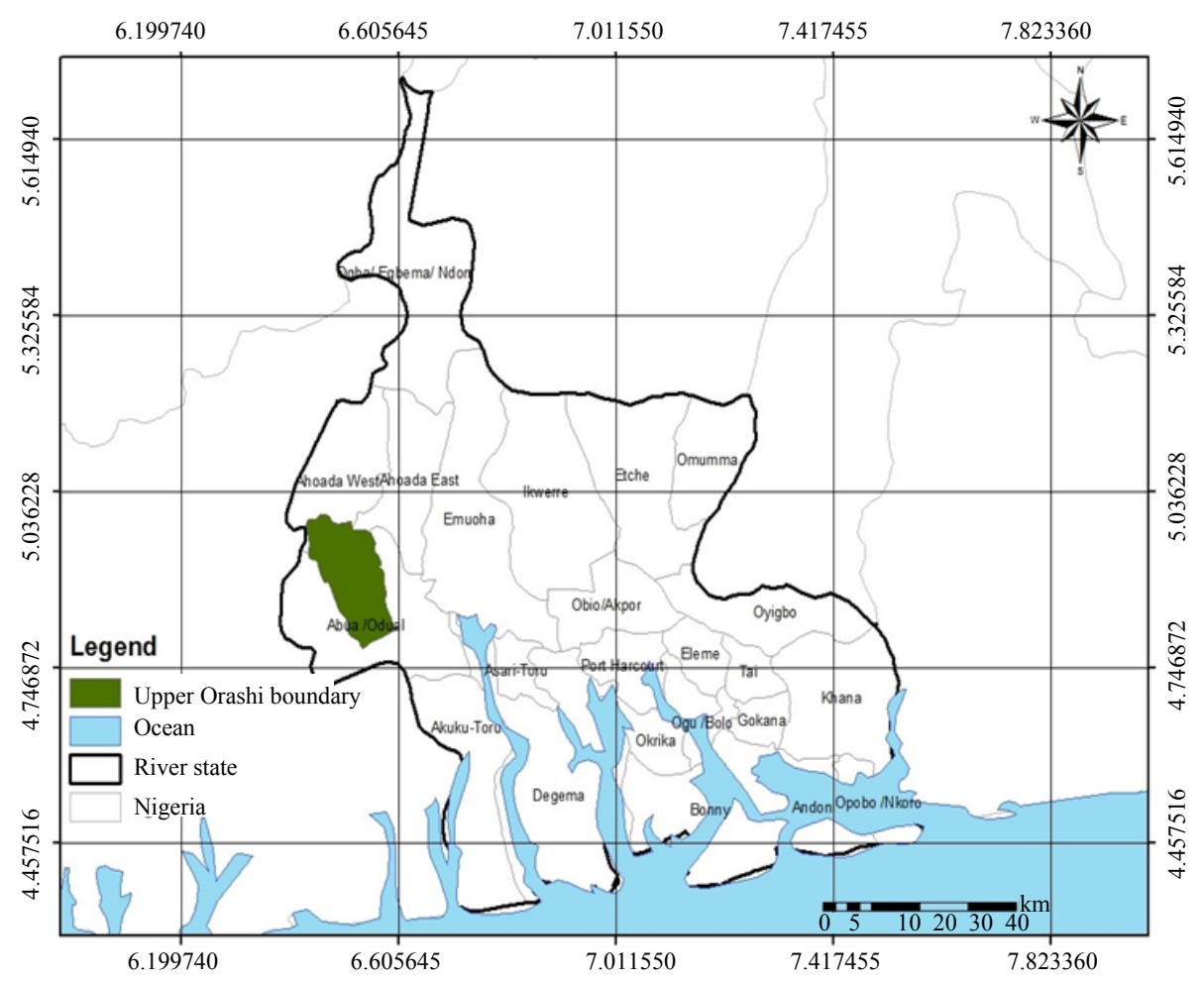

Fig. 2: Map of rivers state showing the study area; Goggle Earth Pro, researcher Digitization with ArcMap 10.5, 2019

a mean annual rainfall of $3789 \mathrm{~mm}$ with the peak of the rainfall occurring in June and September with 670 and $516 \mathrm{~mm}$, respectively usually separated by an August low of $318 \mathrm{~mm}$. It is usually inundated from September to November by flood water from the Orashi river causing siltation and soil fertility augmentation. The sky is overcast skies almost all the time with mean temperature ranging from $24^{\circ} \mathrm{C}$ in August to $27^{\circ} \mathrm{C}$ in April.

Population: The forest reserve is endowed with abundant flora and fauna species. The varieties of habitat types within the reserve include the swamp forest which is the dominant ecosystem, mangroves and rainforests with popular tree species such as the oil palm (Elaeis guineensis) is common and rattans (Calamus deerratus) dominate the under-story. Nigeria's second most important timber species, Abura (Hallea Ledermannii), once common in the area has been removed by extensive logging, since, the late 1950 's. The reserve is a remnant of a small centre of endemism and supports critically endangered Sclater's guenon, endangered White-throated guenon, red colobus monkey, Ogilby's duiker and pygmy hippopotamus. It also provides a major roosting site for the grey-parrot (Psittacus erithacas), hosts a number of waterbird and also supports 91 other arboreal species in 34 families such as Hartlaub's duck, Congo serpent eagle,
Guinea turaco, white-crested hornbill, Blue-headed wood dove. A number of other species have been recently discovered in the area that are new to Nigeria include the black-fronted duiker, pygmy scaly-tailed flying squirrel and small green squirrel.

\section{Literature review}

Conceptual framework

Environmental justice: Environmental justice is in large part the application of justice inquiry to environmental problems. Environmental issues are usually explored through social movements and analytical approaches. It is basically about the movement and is applied to communities where the disadvantaged (whether due to their race, ethnic, socio-economic status and so on) are put at disproportionate risk of being exposed to environmental hazards (Luz, 2007). There is no universal definition for enviornmental justice, different individuals, communities and institution defined environmental justice based on place, time and perspective. It deals with the concept of fairness, it emphasizes the fair distribution of harms and benefit and that each person has an equal right to a fully adequate scheme of equal basic rights and liberties within the environment (EPA, 1992). Environmental justice is the fair treatment and meaningful 
involvement of all people regardless of race, color, national origin or income with respect to the development, implementation and enforcement of environmental laws, regulations and policies. Fair treatment means that no group of people including a racial, ethnic or a socioeconomic group should bear a disproportionate share of the negative environmental consequences resulting from industrial, municipal and commercial operations or the execution of federal, state, local and tribal programs and policies while meaningful involvement means that $\mathrm{k}$-the potentially affected group should have an opportunity to contribute to and participate in making decisions about their environment and at the same time influencing the regulatory agency decision through their contributions. Environmental justice refers to those cultural norms and values, rules, regulations, behaviors, policies and decisions to support sustainable communities where people can interact with confidence that the environment is safe, nurturing and productive.

\section{Literature review \\ Wetland ecosystems and their ecosystem services:} Wetland ecosystems which are an important environmental or natural resource form part of the total wealth of a nation (Ajibola et al., 2016). These ecosystems produce disproportionately more services relating to human well-being than most other systems (MEA., 2005). They are complex multifunctional ecosystems providing diverse interdependent ecosystem services to multiple actors. Wetlands have been described both as the kidneys of the landscape because of the functions they perform in the hydrological and chemical cycles and as biological supermarkets because of the extensive food webs (Ramsar, 2009c) and rich biodiversity they support (Edwards and Kudret, 2017). Wetlands typically represents transition zones between permanently wet and generally dry environments which evolve overtime starting with open waters that continuously experience gradual infilling by sediments and vegetation and eventually become dry land (Edwards and Kudret, 2017). Wetlands are long referred to as watelands but now they are now recognised as important features in the landscape that provide numerous beneficial services to people, fishes and wildlife (USEPA., 2006). Based on formation, the different types of wetlands include inland wetlands, coastal wetlands and human-made wetlands. In the same vein, the National Act No.36 of 1998 of South Africa defines wetlands as areas of transition between aquatic systems and terrestrial systems, where the water table is usually at the surface and can support vegetation that can typically adapt to life in saturated soil. The Niger Delta is one of the world's 10 most important wetland and coastal marine ecosystems and is home to some 31 million people. It is the largest wetland and maintains the third-largest drainage basin in Africa. The Delta's environment can be broken down into four ecological zones: costal barrier islands, mangrove forests, freshwater swamps and lowland rainforests (Ajibola et al., 2016). This is incredibly a well-endowed ecosystem which contains one of the highest concentrations of biodiversity on the planet (United Nations Environmental Programme (UNDP)s, 2007).

Wetland ecosystems: Coastal wetlands, especially, those in the Niger Delta region are considered amongst the most bio-diverse on earth and within these wetlands, distinct vegetation types such as the mangroves, freshwater swamp forests and lowland rain forests are found.

Swamp forests: These are vast fresh water forests and are characterized by considerable biodiversity and ecological fragility. The swamp forest within a coastal wetland are often separated from the ocean by a band of mangrove on the coast (Adams, 2016). Beneficial services that the swamp forest offers include gas regulation, disturbance regulation, water regulation, water supply, waste treatment, habitat refuge, food production, raw materials recreation and cultural services (Costanza et al., 2014).

Rainforests: These are mostly the predominant ecosystem types in the non-riverine areas of the environment. These forests are found in areas where the rainfall is high but the soil is excessively well drained. Rainforest ecosystems are host to a rich assemblage of species and provide a wide range of ecosystem services such as food, medicines, building materials, shelter and store houses for carbon. Cancer Institute has identified 3000 plants that are active against cancer cells; $70 \%$ are found in rainforests (The Economics of Ecosystems and Biodiversity (TEEB), 2009).

Mangroves: Mangroves are the dominant ecosystems along the tropical coasts around the world with their roots submerged in water, thriving in hot, muddy and salty conditions. These ecosystems are often found dividing the ocean and the swamp forests (Fund, 2014). Mangroves are extremely productive ecosystems that provide good and services both to the marine environment and people. They act as sponge in absorbing flood waters and sinks for retaining pollutants from contaminating the tidal waters. This ecosystem also plays important role in climate change mitigation because of its high blue carbon sequestration potential. The uniqueness 
of the mangrove ecosystems is its protection against erosion, storm, flood and global warming. Mangroves improve water quality, helps in waste disposal and energy resources.

Wetland loss and degradation: Wetlands provide important and diverse benefits to people around the world at both local and global levels, these benefits include provisioning services, regulatory services, cultural services and supporting services. Critical regulating services include water-quality improvement, flood abatement and carbon management, while key habitat services are provided by wetland biodiversity. However, much of the world's wetlands have been lost due to series of occurrences most especially human induced which gradually cause the depletion of this productive element of the ecosystem. Human perception of wetlands as unproductive, unhealthy lands, full of disease carrying insects and reptiles such as snakes and crocodiles is a major cause of the loss and degradation (Ajibola et al., 2016). The unprecedented rate of wetland loss has led to several alterations in the services it provides and the continous exploitation of wetlands for one service affects it ability to provide other services (Day et al., 2000; Finlayson, 2005). The declining condition of wetlands has placed their ecosystem services and the people who depend on them at increasing risk about $50 \%$ of the world's wetlands have been depleted out of 1,280 million hectares. In New Zealand, more than $90 \%$ of wetland area has been depleted in the last 150 year, having the highest records of wetland depletion in the world. These loss and degradation are associated with reclamation of wetlands for other uses, infrastructural development, land conversion, water withdrawal, pollution, harvesting, over exploitation and introduction of massive alien species. The impact of the loss and degradation is mostly felt in coastal wetlands than any other type of wetlands. Coastal wetlands lie between land and ocean and are threatened by human activity and natural hazards such as climate change, sea level rise, local subsidence, decreased sediment supply and acidification. Mangroves as a type of coastal wetland have been degraded about $50 \%$ in the last decades, most of which was transformed into mariculture ponds (Valiela et al., 2009). Wetlands are important elements of Nigeria's watershed systems (Uluocha and Okeke, 2004; Chidi and Erhabor, 2009). The rate of wetland loss has been so drastic as the rich wetlands are being seriously threatened by a number of anthropogenic and biophysical factors Uluocha and Okeke (2004). Some of the notable human actions include population pressure, rapid urbanization, mining, oil and industrial waste pollution, overgrazing, logging, dam construction, transportation routes and other physical infrastructure
Uluocha and Okeke (2004). Other factors are uncontrolled tilling for crop production and unprecedented/unregulated land reclamation. Subsidence, saltwater intrusion, sand storm, desertification and droughts, invasion by alien floral and faunal species as well as marine and coastal erosion are natural threats to wetlands in the country. Wetlands destruction affects negatively water supply and water resources management.

Environmental justice as a tool for environrmental managemnt: Issues of environmental injustice globally are really complex, they often exist between developed and developing countries and relate to environmental degradation which cannot support healthy living, food security and climate stability. The basis of all environmental justice variations is the consideration of fairness, equity and justice in the environmental processes that resolve environmental problems. Historically, the concept of Environmental justice originated from the civil liberties campaigns of the 1960's which was concerned with widespread distributive inequalities reflected as discrimination mainly on the basis of race and economic status in environmental matters. In the United States, Environmental justice is basically tailored towards distribution at the expense of participation and the attention given to the issue relating to procedural equity in the movement was minute. Before now, Environmental justice focused basically on distributive inequalities by seeking to understand the processes that created the injustices. The more recent approaches to Environmental justice have taken a multidisciplinary and global dimension. At the local and national levels, the quest for Environmental justice is cutting across gender, demographic, health, ethnic, social and legal concerns. At the international level, there have been increased calls for countries dialogue on the impact of global environmental problems and challenges such as the effect of transboundary export of hazardous waste, impacts of climate change, global warming, deforestation, loss of biodiversity and many other global environmental ills. The concern for Environmental justice have become more profound owing to the diversity and gravity of global environmental problems such as global warming and climate change, natural resources depletion and widespread air and water pollution. The effects of these global environmental problems have been predicted to affect inhabitants of developing countries more than those of the developed ones. Part of the injustice wrought experienced globally is a lack of recognition and so, destruction of various cultural identities including cultures ties to the land. A major step to reduce the effects of these injustice was catalyzed by the Environmental Justice National Forum (EJNF) an organization established in 
the 1990's to coordinate activities of environmental organizations engaged in social and Environmental justice. South Africa is majorly into extractive activities and has the richest coal and gold mines in the world with a string of closed mines leaving behind toxic legacies and long-term risks for human health and the environment. A particular problem has been trends of silicosis among gold miners, a life-threatening disease caused from inhaling silica from gold. In recognizing that environmental damage has the greatest impact upon poor people, EJNF seeks to ensure the right of those most affected to participate at all levels of environmental decision-making (EJNF, 1997). Therefore, Environmental justice should be increasingly used to connote inclusiveness in addressing global, national and grassroots environmental problems. The tendency to move beyond the traditional description of Environmental justice as being distributive is now very high due to the realization that distributive Environmental justice aspects are inadequate in addressing historical and present day environmental challenges.

\section{MATERIALS AND METHODS}

This section of the research discusses the research design, study population, the sample frame, sample size and its characteristics, the sampling methods adopted, sources and instruments of data collection, data analysis and presentation.

Research design: Research design is the strategy, the plan and the structure of conducting a research project. The case study research design was employed for the purpose of this research work. It involves an in- depth investigation and observation of any natural phenomenon which exists in a set of data. It provides a systematic way of observing the events, collecting data, analyzing information and reporting the results over a long period of time. This approach has to do with studying a phenomenon within its real-life setting therefore ensuring an in-depth study of issues from varying perspectives. For the purpose of this research, all the institutions that are directly and indirectly involved in the affairs of forests and wetland management will be identified. However, the agencies that are directly involved in the forest affair were selected as sample size. Denscombe in 2007 identified criteria that are to be employed in justifying the selection of particular case studies. The criteria include Suitability criteria, pragmatic criteria and no real choice criteria.

Research population: Research population refers to the totality of individuals, animals, plants and other elements under study. It is generally a large collection of individuals or objects that is the focus of a scientific query. For this research work, the population was taken to be the totality of the wetland ecosystems of Upper-Orashi Forest Reserve. These include water bodies, the various flora species and fauna species such as swamp forests, the rain forests and the mangroves. In addition, the target population include specialists in wetlands and wetland management and various institutions and agencies that deal with the protection, management and development of forests within the state were will be put into consideration.

Sampling frame: The sampling frame for this research was taken to be the biomes that falls within the study area. These include the swamp forest, evergreen rainforest, mangroves and water bodies. The sampling frame also specialists in wetland management and all the agencies and institutions that are directly involved in forest management in the state. These agencies include.

Forest Research Institute of Nigeria (Swamp Forest Research Station), Niger Delta Wetland Centre, River State Ministry of Agriculture, River State Ministry of Environment, River State Ministry of Energy and Natural Resources, River State Ministry of Water Resources and Rural Development.

Sample size: These include water bodies, the various flora species and fauna species such as swamp forests, the rain forests and the mangroves and specialists in wetlands and wetland management. Also, the sample size was selected using the suitability criteria and pragmatic criteria for the agencies directly involved in coastal management. The information obtained from each of the agencies will determine their selection. Based on the selection criteria, two agencies that are directly involved in the affairs of Upper Orashi forests were selected. They are River State Ministry of Agriculture and Forest Research Institute of Nigeria (Table 1).

Sampling technique: Geographic Information Systems and Remote Sensing (GIS\&RS) was also employed to perform geospatial analysis regarding the wetland ecosystems in Upper Orashi. This was used to determine the ecosystems and their depletion over the years. This technique was also assisted in the quantification of the wetland ecosystem in Upper Orashi using the hectares covered by each ecosystem.

Data collection instrument: Qualitative data were used in this study because it seeks to dive deep into the topic at hand to gain information about people's view, opinion and attitude, thereby giving room for in-depth understanding of the research questions so as to achieve all the pre-determined objectives. 
Environ. Res. J., 13 (1-4): 35-50, 2019

Table 1: Summary of sample size selection criteria

\begin{tabular}{|c|c|c|c|}
\hline \multirow[b]{2}{*}{ Agencies } & \multirow[b]{2}{*}{ Data information } & \multicolumn{2}{|l|}{ Response } \\
\hline & & 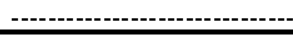 & ----- \\
\hline Forest Research Institute of Nigeria (Swamp & Test site for theory & Interested & \\
\hline Forest Research Station) & & $\begin{array}{l}\text { Willingness to cooperate } \\
\text { Convenient }\end{array}$ & Yes \\
\hline Niger Delta Wetland Centre & Test site for theory & $\begin{array}{l}\text { Interested } \\
\text { Not willing to cooperate } \\
\text { Convenient }\end{array}$ & No \\
\hline River State Ministry of Agriculture & Typical instance & $\begin{array}{l}\text { Interested } \\
\text { Willingness to cooperate } \\
\text { Convenient }\end{array}$ & Yes \\
\hline River State Ministry of Environment & Typical instance & $\begin{array}{l}\text { Interested } \\
\text { Not willing to cooperate } \\
\text { Convenient }\end{array}$ & No \\
\hline $\begin{array}{l}\text { River State Ministry of Water Resources and } \\
\text { Rural Development }\end{array}$ & Typical instance & $\begin{array}{l}\text { Interested } \\
\text { Not willing to cooperate } \\
\text { Convenient }\end{array}$ & No \\
\hline
\end{tabular}

Researcher field work, 2019

Table 2: Sources of data for the research

\begin{tabular}{lllc}
\hline Dataset name & Years & Units & Resolution (m) \\
\hline Landsat use classification Land Landsat 4 & 1988 & $\mathrm{~km}^{2}$ & 30 \\
Landsat use classification Land Landsat 7 & 2003 & $\mathrm{~km}^{2}$ & 30 \\
Landsat use classification Land Landsat 8 & 2018 & $\mathrm{~km}^{2}$ & 30 \\
Ecosystems dataset Ecosystems dataset & & & 30 \\
Ransar polygon upper orashi boundary & & & \\
TEEB database valuation data & & & \\
\hline
\end{tabular}

esercher field work in 2019

Sources of data: Data used in this research were acquired from both primary and secondary sources. Spatial data and imageries were obtained to assess the ecosystem depletion over time. Valuation data were also obtained from TEEB database to assist with quantification of the ecosystems and their services. Lastly, interview guides were used to elicit information regarding environmental justice practices in the sustenance of the Upper Orashi forest to improve well-being of both the local and national communities and the ecological environment.

Primary sources: Data gotten from these sources are raw and unprocessed in nature and are usually acquired during direct contact with the research population or sample. For this research, observation and well-structured interview guides were used to obtain relevant information about the target population. Information were obtained about the wetland ecosystem services, dominant anthropogenic activities in Upper Orashi forest reserve from specialist who had carried out a number of researches on the forest reserve. In addition, information about the effort made over the years by the managing bodies to curtail the depletion of the wetland ecosystem were sampled. Personal interview through the use of a well-structured interview was used to obtain information about the wetland ecosystem, its existing management initiatives, especially in the aspect of the concept of environmental justice application. The research also obtains information on efforts that have been put in place by relevant institutions to ensure environmental justice in the management of the Upper Orashi forest ecosystem.

Secondary sources: Data obtained from these sources are already collected and sometimes processed data which are usually retrieved from already existing literature. Secondary data that were used in this research were obtained through consultation of existing reports, abstracts, archival records and journal. Likewise, this research as well involved extensive use of spatial data which were obtained from secondary sources such as the satellite imageries, Google Earth and Landsat imageries. All these were used as dataset to carry out a multi-criteria analysis to map out the Upper Orashi Forest reserve. Furthermore, this study also obtaine ecosystem valuation dataset from The Economic Ecosystem and Biodiversity (TEEB) which assisted in the monetary quantification of the ecosystems and their services (Table 2).

Procedure for data collection: The study started by obtaining spatial data regarding the physical boundaries of the Upper Orashi wetland. This was obtained from the RAMSAR site as a polygon shape file. This shape file was overlaid on a spatially disaggregated ecosystem dataset obtained from USGS. A spatial analysis task 'Extract by Mask' using ArcGIS 10.5 was performed which ensures that the ecosystem data was extracted into the polygon boundary shapefile as output data. The study then overlaid the output on landsat imageries for years 1988,2003 and 2018 to ascertain the depletion of the 


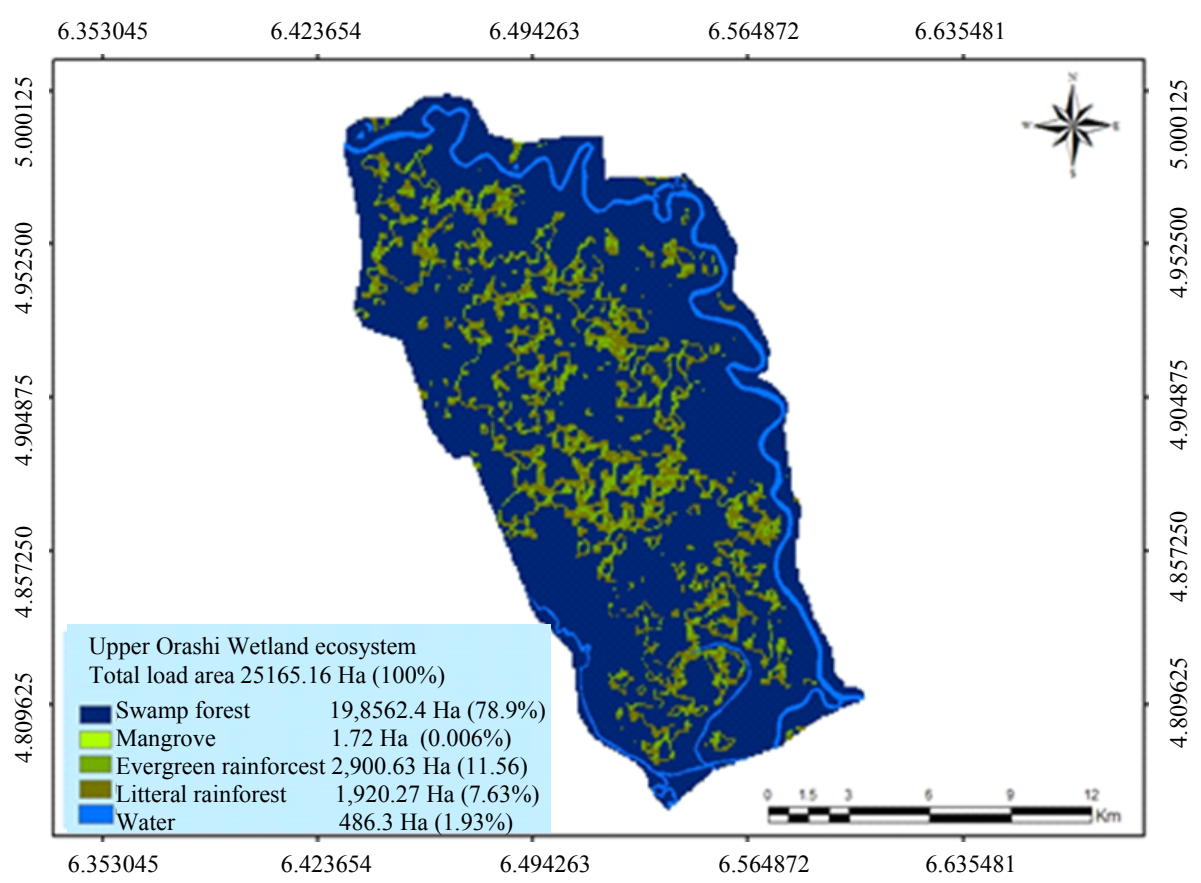

Fig. 3: Ecosystems within Upper Orashi forest reserve Researcher field work in 2019

wetland ecosystem over time. The obtained historical datasets were subjected to transformation, image analysis and composition on Erdas 9.2. Principal Component Analysis (PCA) was carried out on the composed dataset after which the datasets were classified into four different classes using the supervised classification GIS technique. The study then performed change analysis which revealed the areas depleted within the wetland ecosystem through maps.

Method of data analysis: Data collected were subjected to univariate analysis which involve expression of data in percentages. Also, the extent of the various ecosystems in the study area were assessed using Geographical Information System (GIS) and Remote Sensing (RS) for the base year 1988 and changes were assessed for the cardinal year 2003 through 2018. The TEEB database was used to establish the monetary value of the ecosystems in its pristine state and depleted state. The responses of the interviewees captured during interview session with the use of sound recording devices was transcribed using content analysis for qualitative research with the aid of Microsoft Excel package. This was used in conjunction with a systematic performance indicator in assessing the performance of the agency involved in the management of Upper Orashi forest for Environmental justice. The principles of Environmental justice were used as the set of indicators assessed against the performance indicators.

\section{Data analysis and interpretation}

Introduction: This chapter presents the result of the analysis of the research work based on the research questions and objectives. Content analysis was used to analyse all the responses of the interviewee and a GIS based Model is also adopted to carrying out spatial analysis. The results of these analyses are presented in four sessions with each sections addressing the research objectives. The first section deals with the various wetland ecosystems in the study area and the services these ecosystems provide while the second section evaluates the extent of depletion of each of the ecosystems within the forest reserve over the period of 30 years. The fourth section examines the level of justice in the existing management strategy adopted for managing the forest.

Ecosystems within Upper Orashi forest reserve in 1988: The result of analysis (Fig. 3) reveals that there are five different ecosystems within Upper Orashi forests. They include the Swamp forest, Mangrove, Evergreen rainforest, Littoral rainforest and Water bodies, all covering a total land area of $25,165.16$ ha. About $79 \%$ of the total land area of the forest reserve was swamp forest. Collectively, the rainforest covered $20 \%$ of the reserve with nearly $12 \%$ evergreen rainforest and about $8 \%$ littoral rainforest, Mangrove ecosystem covered $0.01 \%$ and water bodies covered about $2 \%$ of the forest reserve. 
Environ. Res. J., 13 (1-4): 35-50, 2019

Table 3: Upper-Orashi forest ecosystem valuation per year

\begin{tabular}{|c|c|c|c|c|c|}
\hline \multirow[b]{2}{*}{ Ecosystems } & \multirow{2}{*}{$\begin{array}{l}\text { Total land } \\
\text { Area (ha.) }\end{array}$} & \multicolumn{2}{|c|}{ Ecosystems land area depletion in 2003} & \multicolumn{2}{|c|}{ Ecosystems land area depletion in 2018} \\
\hline & & Hectares & Percent & Hectares & Percent \\
\hline Swamp forest & 19856.24 & 1556.46 & 6.185 & 2056.77 & 8.173 \\
\hline Mangrove & 1.72 & 0.56 & 0.001 & 1.04 & 0.006 \\
\hline Evergreen rainforest & 2900.63 & 8.55 & 0.034 & 30.78 & 0.122 \\
\hline Littoral rainforest & 1920.27 & 5.76 & 0.023 & 18.36 & 0.073 \\
\hline Water bodies & 486.31 & 4.59 & 0.018 & 49.14 & 0.195 \\
\hline Total & & 1575.92 & 6.261 & 2156.09 & 8.570 \\
\hline
\end{tabular}

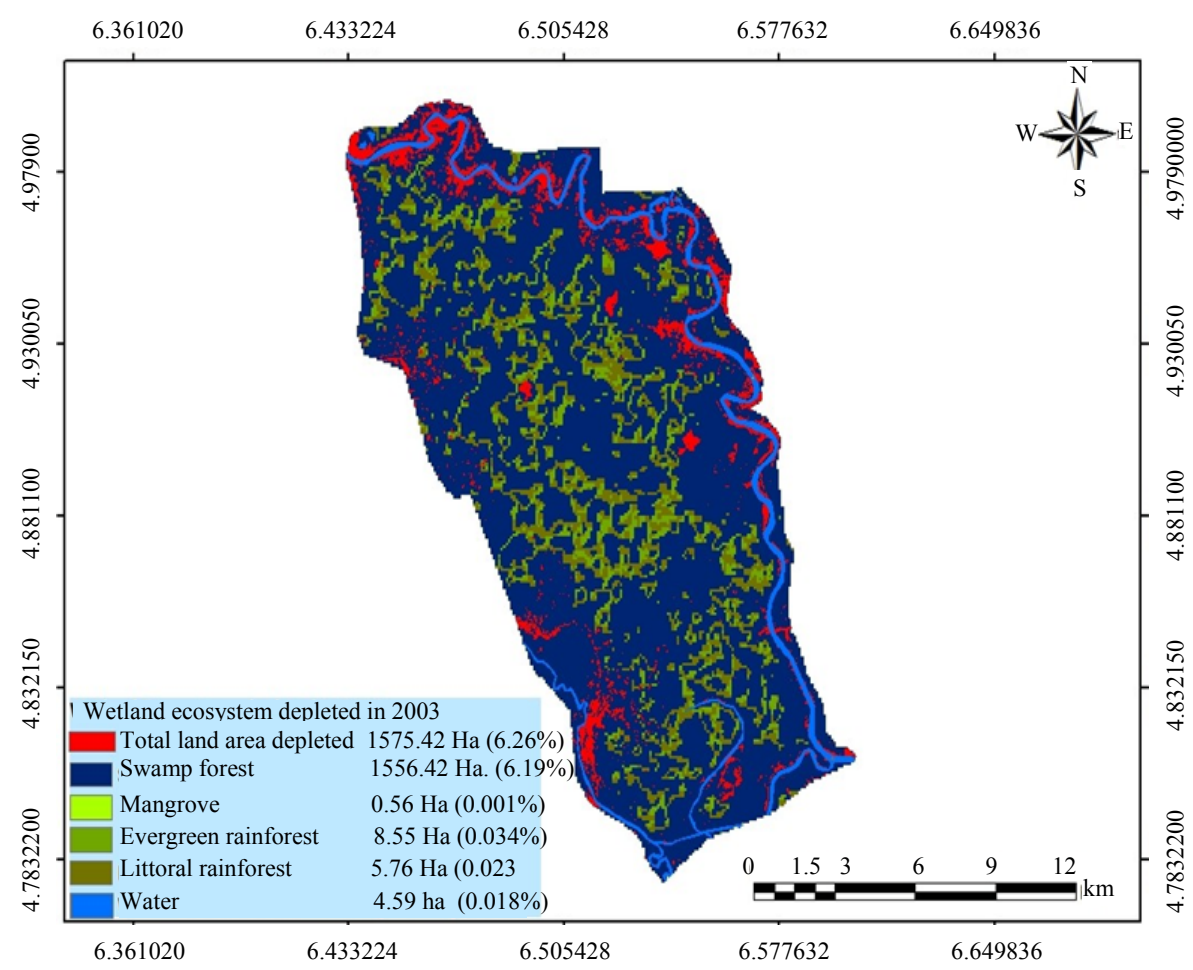

Fig. 4: Wetland ecosystem depletion in Upper Orashi between 1988 and 2003. Resaecher's field work in 2019

Wetland ecosystems depletion: The extent to which the wetland has been depleted is estimated from 2003-2018 using a base year of 1988 . The results of the depletion as displayed in Table 3, Fig. 4 and 5 reveals that 3732.01 ha $(14.83 \%)$ of land had been depleted in the study area with $6.26 \%$ depleted between 1988 and 2003 and $8.57 \%$ depleted between 2003 and 2018 .

Findings as shown in Fig. 5 reveals that $6.19 \%$ of the swamp forest had been depleted between year 1988 and 2003. In the same vein, $0.001 \%$ and $0.018 \%$ of the identified mangrove and water bodies in the forest had been depleted respectively. Collectively, $0.057 \%$ of the rainforests were also depleted during this period.

Result of analysis shown in Fig. 5 reveals that $8.17 \%$ of the swamp forest had been depleted between year 2003 and 2018. Also, 0.006 and $0.19 \%$ of the mangrove ecosystems and water bodies in the forest had been depleted, respectively. Collectively, $0.19 \%$ of the rainforests were also depleted during this period.
About $97 \%$ of all the depletions occurred along the water bodies with the swamp forest experiencing more depletion than any other ecosystem within the Upper Orashi forest. Reason being that the swamp forest is the dominant ecosystem in the forest reserve. From the base year, about 1.72 ha of mangroves were identified due to the proximity of the site to the ocean. However, the result of depletion analysis reveals that about $93 \%$ of the mangrove ecosystem had been depleted over the period of years considered. The reasons for all the depletions are not far-fetched as it was gathered from field survey that there is increasing demand for the services the ecosystems provide. The continuous demand for the ecosystem's provisioning services in form of food lead to the diversion of waters from lakes, streams and river for irrigation, pond and swamp fishing. The conversion of some natural spaces into agricultural land for cultivating farm produce such as cassava, yams, legumes and vegetables. 
Environ. Res. J., 13 (1-4): 35-50, 2019

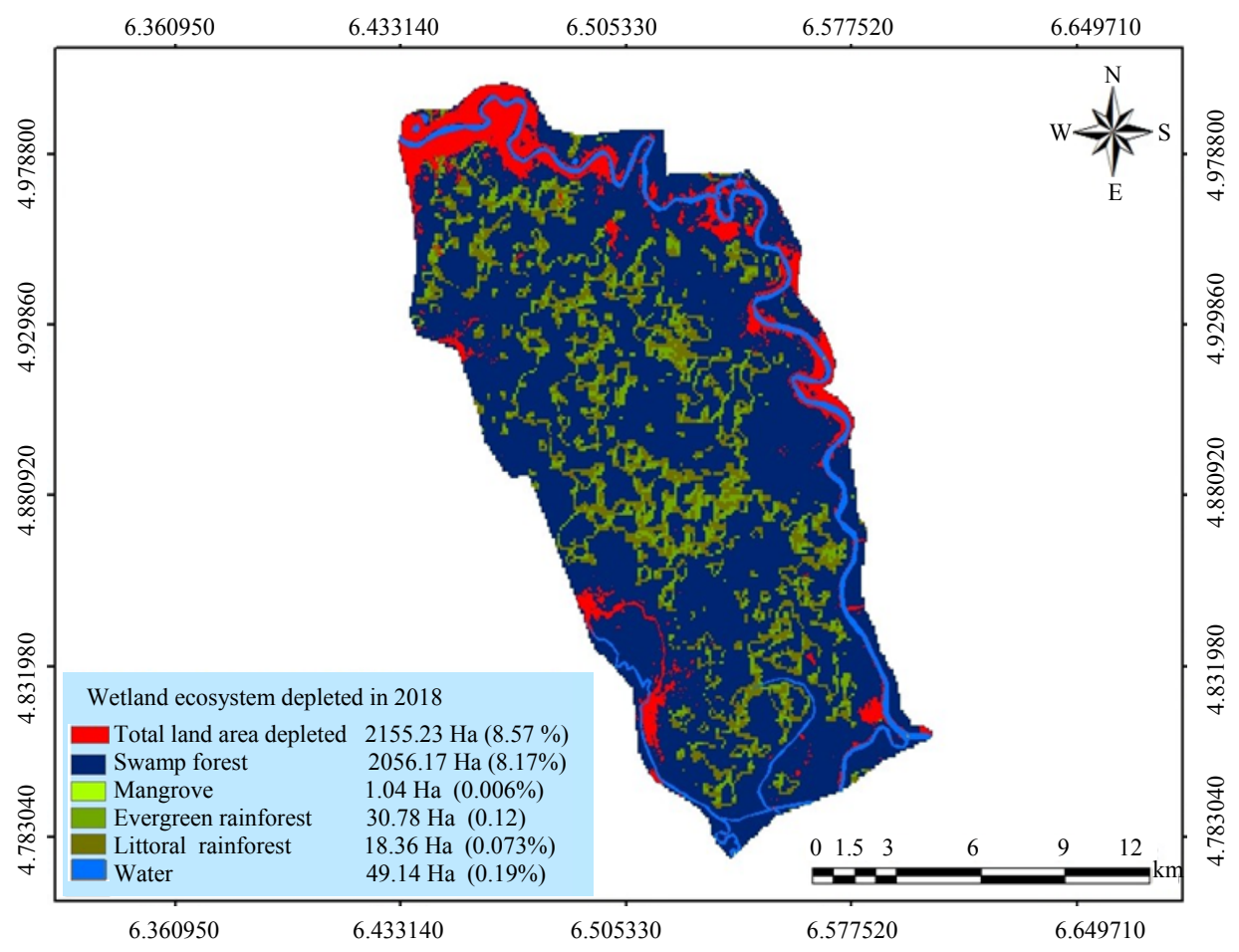

Fig. 5: Performance score for participation criteria. Resaercher field work in 2019

Increasing demand of logs on large scale has also contributed to the depletion of the forest flora species. Other depletion inducing activities in the study area include sand dredging, agro-forestry (oil-palm, banana), collection of wild resources (Irvingia fruits are gathered seasonally), cottage industry and unsustainable firewood collection by local people for domestic cooking. The results of depletion analysis also revealed that issues of ecological injustice are prevalent in the study area. Over the period of 30 years that was considered the rate of exploitation of ecological product is gradually increasing. Between 2003 and 2018, the percentage of land of each of the ecosystems that was depleted is higher than that depleted 2003 and 2018 by $2 \%$. The reasons for this depletions as identified by literature were due to the anthropogenic activities that were concentrated in the area.

Economic value of the wetland ecosystems: For the five ecosystems examined in the study area, the updated global database version of the simple benefit transfer was used to estimate the monetary values of the services gotten from the ecosystems in Upper Orashi per year. The US dollars per hectare as at 2014 based on 2007 International $\$ /$ ha/year. I.e. translated into US\$ values on the basis of the Purchasing Power Parity (PPP) was also applied. The result of analysis in Table 4 shows that the total monetary worth of Upper Orashi forests when not disturbed per year is estimated at $\$ 537.98$ million which is equivalent to
\#2.17 trillion using the conversion rate of N360 to $\$ 1$. Analysis revealed that $95 \%$ of the forest value was attributed to the swamp forest while $1.1 \%$ of the total value was estimated as the value of the water bodies. Collectively, the value of the rainforests was estimated to be about $4 \%$ of the total value of the wetland ecosystems and Mangrove was estimated at $0.1 \%$ of the total value of Upper Orashi wetland ecosystems.

Swamp forest: In the study area, the monetary value of the overall services of the swamp forest in the area was estimated. Results of analysis in Table 3 shows that the total ecosystem services obtainable per year from the swamp forest in Upper Orashi forests was estimated at $\$ 509.92$ million (N183.57 billion) which summed up to $\$ 15.29$ billion (N5.50 trillion) in the 30 years considered. However, as highlighted in Table 4 , about 2056.77 ha of swamp forest has been depleted between 1988 and 2018. The increase in loss of the swamps had a corresponding increase in the services lost which was estimated at $\$ 39.9$ million at 2003 and increased to $\$ 52.8$ million at 2018 per year. The total ecosystem loss for the 30 years amounts to $\$ 1.8$ billion which when converted to naira is N649.2 billion. The services affected include gas regulation, disturbance regulation, water regulation, water supply, waste treatment, destruction of habitats for species of plants and animals, food production, raw materials, recreation potentials and cultural heritages. 
Environ. Res. J., 13 (1-4): 35-50, 2019

Table 4: Upper Orashi forests ecosystems valuation per year

\begin{tabular}{lllll}
\hline Ecosystem & & Total ecosystems & Ecosystems depleted in & Ecosystems depleted in \\
\hline Swamp forest & Area (ha) value (\$/year) at & 19856.24 & 2003.46 & 2038.77 \\
& 25,681 per ha/year & $509,928,044.7$ & $39,971,449.26$ & $52,819,910.37$ \\
Evergreen & Area (ha) value (\$/year) at & 2900.63 & 8.55 & 30.78 \\
rainforest & 5,382 per ha/year area (ha) & $15,611,190.66$ & $46,016.11$ & $165,657.96$ \\
Littoral & Area (ha) value (\$/year) at & 1920.27 & 5.76 & 18.36 \\
rainforest & at 3,137 per ha/year & $6,023,886.99$ & $18,069.12$ & $57,595.32$ \\
Mangrove & Area (ha) value (\$/year) at & 1.72 & 0.56 & 1.04 \\
& at 193,843 per ha/year & $333,409.96$ & $108,552.08$ & $201,596.72$ \\
Water bodies & Area (ha) value (\$/year) at & 486.31 & 4.59 & 49.14 \\
& 12,512 per ha/year & $57,430.08$ & $614,839.68$ & $6,084,671.1$ \\
\hline
\end{tabular}

Researcher field work in 2019

Table 5: Values of Upper Orashi forest ecosystems in 1988

\begin{tabular}{llll} 
& Ecosystem land area depletion in 2003 & \\
& - & Ecosystems land area depletion in 2018 \\
Ecosystems & Hectares & Percent & Hectares \\
\hline Swamp forest & 19856.2 & 25,681 & $509,928,045$ \\
Mangrove & 1.7 & 193,843 & 333,689 \\
Evergreen rainforest & 2900.6 & 5,382 & $15,611,172$ \\
Littoral rainforest & 1920.3 & 3,137 & $6,023,876$ \\
Water bodies & 486.3 & 12,512 & $6,084,671$ \\
Total & 25165.2 & 240,555 & $537,981,453$ \\
\hline
\end{tabular}

Researcher field work in 2019

Evergreen rainforest: Results of analysis in Table 4 show the total value of all the services provided by the evergreen rainforest in Upper Orashi which was estimated per year at $\$ 15.61$ million ( $N 5.62$ billion) and was totalled at $\$ 468.34$ million (N168.60 billion) in the 30 years considered. Due to the anthropogenic activities in the area, about 30.78 ha of the rainforest had been depleted over the period of 30 years. The continuous loss of the rainforests was due to the increasing demand of the rainforest for its services such as for waste treatment, food production, raw materials and genetic/medicinal resources and for recreational purposes. In addition, it provides services such as climate regulation, disturbance regulation, water regulation, water supply, erosion control, soil formation and nutrient cycling. As highlighted in Table 4, the depletions in this ecosystem were estimated at $\$ 46,016$ in 2003 and $\$ 165,657$ in 2018. The study went further by estimating the values of the evergreen rainforest lost between 1988 and 2018. Results indicate that over the 30-year period, the monetary value that has been lost is $\$ 2,061$ million (N742.1 million).

Littoral rainforest: The services provided by the littoral rainforest in Upper Orashi include climate regulation, soil formation, food production and raw materials. Results of analysis in Table 4 show the total value of all these services provided by the littoral rainforest per year was estimated at $\$ 6.02$ million (N2.17 billion). For the period of 30 years being considered, the value of the littoral forest was estimated at $\$ 180.72$ million (N65.06 billion). Loss of littoral rain forest in the area is accompanied with decrease in the services obtainable from this ecosystem in Upper Orashi which resulted to an estimated loss of $\$ 18,069$ for 2003 and $\$ 57,595$ for 2018 as highlighted in
Table 4. With regards to total value of littoral rainforest depleted between 1988 and 2018, results indicate that $\$ 749,868.5$ (N269.95 million) worth has been lost.

Mangrove: The monetary value of the overall services of the mangrove in the area was estimated. Results of analysis in Table 4 show that the total ecosystem services obtainable per year from the mangrove ecosystem in Upper Orashi forests was estimated at \$333, 409 (N120.03 million) which amounts to $\$ 10$ million (N3.60 billion) in the 30 years considered. However, about 1.60 ha of mangrove had been depleted between 1988 and 2018 and the increase in loss of the mangrove has a corresponding increase in the services lost which was valued at $\$ 108,552$ for 2003 and $\$ 201,596$ for 2018 as highlighted in Table 4. Estimating for the 30 years indicates that the monetary implications of mangrove lost is $\$ 3.35$ million which is N1.205 billion.

Water bodies: Findings revealed that the various water bodies that was present in Upper Orashi forest include the lakes, streams and the Orashi river. Analysis as revealed in Table 4 shows the total ecosystem land area for water is 486.31 ha which was valued at $\$ 6.08$ million (N2.19 billion) and amounts to $\$ 182.54$ million (N65.71billion) in the 30 years considered. The value of the water bodies that has been depleted was valued at $\$ 57,430$ in 2003 and $\$ 614,839$ in 2018. Estimating the loss monetarily between 1998 and 2018 within the 30 years considered, the monetary value of water bodies that has been lost due to human activities is $\$ 5.8$ million which is equivalent to N2.1 billion.

In summary, the total value of ecosystem loss in the Upper Orashi forest between 1988 and 2018 is $\$ 1.815$ 


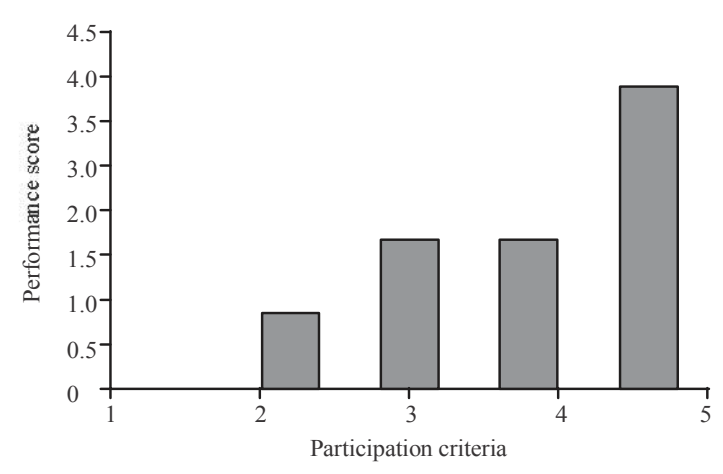

Fig. 6: Performance score for participation criteria

billion which is equivalent to N653.5 billion. Economic valuation of ecosystems is an important indicator of environmental justice. The reason for uncontrolled depletion of the forest ecosystems is basically due to the lack of information on the economic worth of the ecosystems being depleted (Table 5).

Level of justice in the existing management strategy: This section assesses the level of efficiency of the existing management strategy of Upper Orashi forest. This was done using the dimensions of Environmental justice which are participation, information and recognition to ascertain the extent of social injustice in the forest reserve. Several criteria were developed as regards to this dimension and the responses obtained were rated using a performance scoring system established in Table 4.

Participation: Result of analysis in Fig. 6 shows the individual performance scores for each of the criteria identified with an average score of 2.0. This shows that the management system was far below the bench mark of achievement as far as participation is concerned. For criteria 1, addressing the stakeholder's diversity in the management system, this was given the score value 0 because there is no adequate diversity of stakeholders in the management structure and the management practices is often done by the River State Ministry of Agriculture. Manage the forest but were informed about the intentions of the managing body after necessary decision had been made toward the management of the forest. This have a performance score of 1 because the local communities who are closer to the forest were not fully involved in the management of the forest around them and they end up being planned for and not planned as regards to the management of the forest reserve. Criteria 3 which is addressing the role and responsibilities of stakeholders have the performance score of 2 because not all the stakeholders were aware of their roles and responsibilities. The local communities who are supposed to be part of the stakeholders were not even aware of the management processes not to talk of their roles and responsibilities in the management process. Transparency of planning and management process was accessed in criteria 4 and it had score value of 2 which revealed that the system is partially transparent to some selected stakeholder's reasons for doing this was not disclosed in the course of the interview. Finally, criteria 5 addresses the availability of participatory process in conflict resolution. The outcome of findings revealed that several set of procedures have been developed to foster understanding and allow for conflict resolution but have not been well established and implemented as part of the management system. This was given the score value of 4 . In the assessment carried out on the management system of Upper Orashi Forest Reserve, it was deduced that none of the criteria of participation used met the standard bench mark of achievement. This shows evidences that there were no constructive management in operation as far as environmental justice is concerned because one of the key dimension of Environmental justice which is participation have not been adequately provided for in the management system.

Information: The study went further to access the level of information that were made available to the local communities about the management of the forest reserve. Four criteria were used for this assessment and were scored appropriately. The average score of information as a sub dimension of Environmental justice was 1.75. Criteria 1 was given the score value of 0 because the communities had no access to relevant information about the forest around them. Criteria 2 was given the score value of 3 because there are means of disseminating information to local communities which include visiting and telephone calls to some community heads. However, these means were not well established as local communities could not easily convey their observation and opinions about the forest to the appropriate authorities. Criteria 3 addresses how the information passed through available means are well understood. Often times, the local communities were being told about what they already know about the forest. Critical information that are necessary to enhance effective conservation of the forest were usually confined among the decided stakeholders excluding the communities. Criteria 4 which addresses awareness about the management processes and understanding of its relevance, this is given the score value of 0 because the local communities were not aware of the management processes let alone understand its relevance. All they were aware of is that there is a management system on ground but do not understand the processes of the management system.

From findings about effectiveness and adequacy of information between the managing body and the local communities on the management of Upper Orashi forest reserve, it can be deduced that none of the information criteria used meet the standard bench mark of achievement. This also reveals that there are no 
Environ. Res. J., 13 (1-4): 35-50, 2019

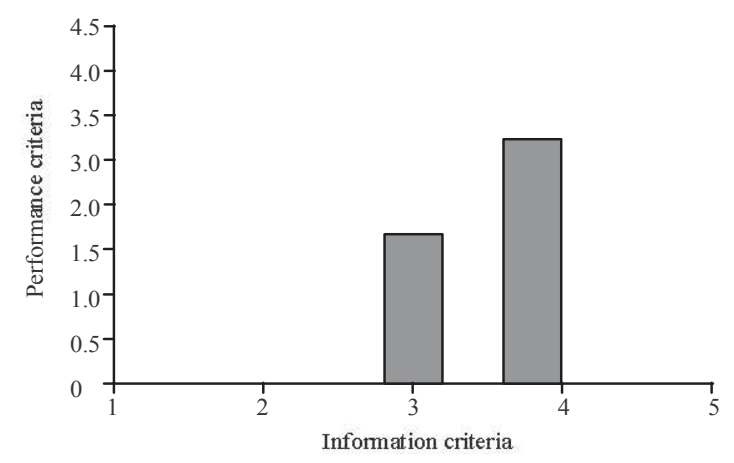

Fig. 7: Performance score for information criteria

constructive management in operation as far as Environmental justice is concerned because information is not well passed across to the local communities within and around the forest environment (Fig. 7).

Recognition: The final dimension of environmental of justice used to access the level of efficiency of the management system is recognition. This was employed to access the level of social and ecological recognition in the management structure that have been established for Upper Orashi forest reserve. Three major criteria were used and the average performance score for recognition Criteria 1 was given the score value of 8 because the management system considered both marketable and non-marketable values of the forest reserve with respect to food, raw material, climate regulation, flood attenuation, education and recreational potentials of the site. That is, the aim of the management was to ensure sustainability of the services provided by forest. Criteria 2 was scored 0 because the management system was not developed around the cultural context of the people that is the belief, occupation, tradition and culture of the people was not considered and this was evident because the people were not involved at the decision making stage and the system of management was alien to them giving rise to agitation and the communities were demanding the right to control the forest around them. Also, the issue of vesting all land in the state government is making no sense to the communities because they were not properly informed various policies that surrounds land ownership in the state. Also, criteria 3 was given a performance score of 0 . This implies that the local people were not seen as an important member of the decision making team and were not effectively involved in the process, their views and interests in the forest were not considered at all in the management process developed for Upper Orashi forest reserve.

Result of analysis as shown in Fig. 8 revealed that the level of justice in the existing management strategy of Upper Orashi Forests is very low. Collectively, participation, information and recognition which were used as performance checking tools were below the standard benchmark of achievement of environmental

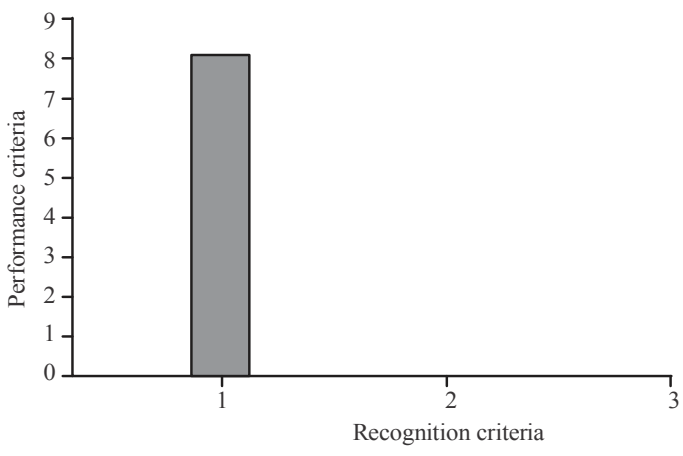

Fig. 8: Performance score for recognition criteria

justice in a management system. According to Bullard in 1995, environmental justice oriented management system would be developed around participation. This would directly include all the impacted stakeholders in order to satisfy questions of social equity. Once the issue of participation is addressed, environmental decision making will reflect the race, ethnicity, class, culture, lifestyles (Fig. 8).

This chapter concludes the study by summarizing the major findings and conclusions drawn thereof. The implications of these research findings are considered as the basis upon which policy recommendations are suggested. Suggestions and recommendations are also made as regards the Upper-Orashi forest reserve towards management.

Summary of findings: Upper Orashi forest reserve is a fresh water swamp forest composed majorly of the swamp forest with other ecosystems such as the rainforest, some strands of mangrove and water bodies which collectively covers a land area of $25,165.16$ ha. Being a small centre of endemism contain some endangered fauna species which is a major criterion for confirming the ecological community a wetland of international importance. The study reveals that Upper Orashi forest contains $78.9 \%$ of swamp forest, $11.5 \%$ of evergreen rainforest, $7.6 \%$ of littoral rainforest, $1.9 \%$ of water bodies and $0.01 \%$ of mangrove. Collectively these ecosystems provided certain benefits to the local and national communities which include the food and fresh water supply, erosion and flood control, biodiversity hotspot, educational and scientific research opportunities. These benefits of the forest to the communities can be grouped under the four major ecosystem services of a wetland environment as identified by the millennium ecosystem assessment in 2005 . However, the demand of the forest for certain services is affecting the ability of the forest to provide services other effectively. Findings revealed that about $14.8 \%$ of the forest has been depleted over the past 30 years due to the increasing demand of the forest for food timber and agricultural land. About $14 \%$ of all the depletions occur in the swamp forest being the dominant ecosystem in the area. The total monetary worth of all the services 
provided by the forest was estimated at 537.98 million USD which is equivalent to 2.17 trillion per year which summed up to $\$ 16.14$ billion (t 5.81 trillion) over the past 30years if not depleted. However, $\$ 94.09$ million (A 33.87 billion) of the total worth of Upper Orashi forest have been depleted over the considered period of years with the present value of the forest at $\$ 16.05$ billion 5.78 trillion).

The study also revealed that the platforms developed for participation, information and recognition in the existing management system is very weak. The top-down approach was adopted in the system of managing Upper forest giving the local communities little or no opportunity to contribute in the decision made to manage the forest. Since, participation was not well addressed, the issues of recognition and information are also left unattended to. These dimensions that is participation, information and recognition depend on each other for effectiveness. This implies that social injustice as an aspect of environmental justice is prevalent in Upper Orashi forest reserve and has brought about ecological injustice to the ecological community who is at the receiving end of the actions of both the managing body and the local communities.

\section{CONCLUSION}

This study assesses the extent of injustice to the Upper Orashi forest reserve. This was achieved by ascertaining the extent of depletion of the ecosystems over a 30 year period and expressing the depletion monetarily through a valuation process. The study then assesses the activities of the management system in charge of the forest to ascertain progress made towards Environmental justice through a suite of Environmental justice indicators and sets of performance guidance notes. Between 1988 and 2018, 14.83\% of the total area of the Upper Orashi forest has been depleted due to unsustainable human activities and poor management of the forest. This consequently has an effect on the various ecosystems and their services. The services affected include gas regulation, disturbance regulation, water regulation, water supply, erosion control, soil formation, nutrient cycling, waste treatment, destruction of habitats for species of plants and animals, food production, raw materials, genetic resources, recreation potentials and cultural heritages. When valued monetarily, the ecosystem services lost, i.e., Environmental injustice amounts to $\$ 1.815$ billion which is equivalent to $\mathrm{N} 653.5$ billion.

Furthermore, the management system in place for managing the Upper Orashi forest reserve performed poorly as their management activities when assessed did not meet the standard achievement mark. This confirms that there are Environmental injustices in the study area as none of the dimensions of Environmental justice assessed shows that the management system is operating in such a manner as to have a greater chance of fostering Environmental justice. However, the recognition dimension shows that there are some evidences of proactive and constructive management in place with some of the criteria performing sub-optimally.

Contribution to knowledge: This study has immensely contributed to the existing stock of knowledge on wetlands and wetland management as it examines the various ecosystems within the wetland environment. it services to both the local communities and the nation at large. Also, these estimates can be used for project appraisal where ecosystem services lost must be weighed against the benefits of a specific project.

Areas for further research: The wetland ecosystem which is the habitat of different plant and animal species is a very sensitive ecological community in the face of depletion, the scope of this study covers the application of Environmental Justice to the management of the wetland. During the cause of the study it was realized that governance is a very vital part of Environmental justice that determines the level of operation of any management system. The management system even after addressing the issues of participation, information and recognition remains limited as a result of this another area for further research.

\section{RECOMMENDATION}

This study thus recommends the continuous assessment of ecosystems in the study area and the periodic valuation of ecosystem services as this will raise awareness to detailed analysis of various policy choices and scenarios regarding ecosystem use. The valuation exercise is also useful for urban and regional land use planning as well as in payments for ecosystem services. The study recommends the use of a suite of environmental indicators tools to the continuous evaluation of Environmental justice in management systems responsible for managing and protecting the environment. The suite of indicators as used here is a strategic review tool to assess the effectiveness of management systems towards achieving Environmental justice that is both spatially and temporally repeatable. This will ensure refinement of the environmental justice dimensions together with their criteria to ensure effectiveness of the management system in ensuring the integrity of the ecosystems.

\section{REFERENCES}

Ajibola, M.O., A.M. Adeleke and A.O. Ogungbemi, 2016. An assessment of wetland loss in Lagos metropolis, Nigeria. Developing Country Stud., 6: $1-7$. 
Chidi, H.O. and F.O. Erhabor, 2009. Biodiversity of Wetland and wealth creation in Niger Delta. Int. J. Dev. Stud., 4: 108-115.

Costanza, R., R. de Groot, P. Sutton, S. van der Ploeg and S.J. Anderson et al., 2014. Changes in the global value of ecosystem services. Global Environm. Change, 26: 152-158.

Day, J.W., L.D. Britsch, S.R. Hawes, G.P. Shaffer, D.J. Reed and D. Cahoon, 2000. Pattern and process of land loss in the Mississippi Delta: A spatial and temporal analysis of wetland habitat change. Estuaries, 23: 425-438.

Edwards, M.R. and S. Kudret, 2017. Multi foci CSR perceptions, procedural justice and in role employee performance: The mediating role of commitment and pride. Hum. Resour. Manage. J., 27 : 169-188.

Finlayson, M., R.D. Cruz, N. Davidson, J. Alder and S. Cork et al., 2005. Millennium Ecosystem Assessment: Ecosystems and Human Well-Being: Wetlands and Water Synthesis. Island Press, Washington DC., USA., Pages: 69.

Kirsten, S. and L. Brander, 2004. The Economic Values of the World's Wetlands. Living Waters, Amsterdam

Li, X., R. Bellerby, C. Craft and S.E. Widney, 2018. Coastal wetland loss, consequences and challenges for restoration. Anthropocene Coasts, 1: 1-15.

MEA., 2005. Ecosystems and Human Well-Being: Policy Responses: Findings of the Responses Working Group of the Millennium Ecosystem Assessment. Island Press, Washington, DC.

Odada, E.O., W.O. Ochola and D.O. Olago, 2009. Drivers of ecosystem change and their impacts on human well-being in Lake Victoria basin. Afr. J. Ecol., 47: 46-54.
Ogunkoya, O.O. and A. Dami, 2007. Information sheet on Ramsar Wetlands (RIS)-2006-2008 version: Dagona Sanctuary Lake, Hadejia-Nguru wetlands. Ramsar, Gland, Switzerland.

Schlosberg, D., 2009. Defining Environmental Justice: Theories, Movements and Nature. Oxford University Press, Oxford, UK., ISBN: 9780199562480 , Pages: 238.

Svarstad, H., A. Sletten, R. Paloniemi, D. Barton and M. Grieg-Gran, 2011. Three Types of Environmental Justice: From Concepts to Empirical Studies of Social Impacts of Policy Instruments for Conservation of Biodiversity. In: Assessing the Role of Economic Instruments in Policy Mixes for Biodiversity Conservation and Ecosystem Services Provision, Tingstad, K.M.K. (Eds.). Norwegian Institute for Nature Research, Oslo, Norway, pp: 1-18.

USEPA., 2006. Economic benefits of wetlands. United State Environmental Protection Agency, Washington DC., USA.

Uluocha, N.O. and I.C. Okeke, 2004. Implications of wetlands degradation for water resources management: Lessons from Nigeria. GeoJournal, 61: 151-154.

Valiela, I., E. Kinney, J. Culbertson, E. Peacock and S. Smith, 2009. Global Loss of Mangroves and Salt Marshes. In: Global Loss of Coastal Habitats: Rates, Causes and Consequences, Duarte, C.M. (Ed.). Fundacion BBVA, Madrid, Spain, ISBN: 9788496515840, pp: 107-133.

Wali, E., 2017. Urbanization and loss of wetland in Port-Harcourt Metropolis, Nigeria. M.Sc. Thesis, University of Nigeria, Nsukka, Nsukka, Nigeria.

Young, I.R., 2000. Inclusion and Democracy. Oxford University Press, Oxford, UK. 